Western University

Scholarship@Western

Aboriginal Policy Research Consortium International (APRCi)

2009

Using Ethnographic Methods to Articulate Community-Based Conceptions of Cultural Heritage Management

Julie Hollowell

George Nicholas

Follow this and additional works at: https://ir.lib.uwo.ca/aprci

Part of the Intellectual Property Law Commons

Citation of this paper:

Hollowell, Julie and Nicholas, George, "Using Ethnographic Methods to Articulate Community-Based Conceptions of Cultural Heritage Management" (2009). Aboriginal Policy Research Consortium International (APRCi). 163.

https://ir.lib.uwo.ca/aprci/163 


\title{
Using Ethnographic Methods to Articulate Community-Based Conceptions of Cultural Heritage Management
}

\author{
Julie HOLLOWELL \\ DePauw University, USA \\ George Nicholas \\ Simon Fraser University, Canada
}

How can ethnographic methods help communities articulate and enact their own conceptions of heritage management? This and related questions are being explored through an international research project, 'Intellectual Property Issues in Cultural Heritage'. The project includes up to twenty communitybased initiatives that incorporate community-based participatory research and ethnographic methods to explore emerging intellectual property-related issues in archaeological contexts; the means by which they are being addressed or resolved; and the broader implications of these issues and concerns. We discuss three examples that use ethnography to (a) articulate local or customary laws and principles of archaeological heritage management among a First Nations group in British Columbia; (b) assemble knowledge related to land/sea use and cultural practices of the Moriori people of Rekohu (Chatham Islands) for their use in future land and heritage management policies; and (c) aid a tribal cultural centre in Michigan in crafting co-management strategies to protect spiritual traditions associated with a rock art site on state property. Such situations call for participatory methods that place control over the design, process, products, and interpretation of 'archaeology' in the hands of cultural descendants. We hope that these examples of community-based conceptions of archaeological heritage management, facilitated through ethnographic methods and participatory approaches, will increase awareness of the value of these and other alternative approaches and the need to share them widely.

KEYWORDS Ethnography, Archaeology, Heritage management, Participatory action research, Post-colonial research methods, Intellectual property 
Archaeologists have frequently turned to ethnographic sources to supplement their understanding of past ways of life or to document their own intrusions into presentday landscapes and cityscapes. But what if the locus of ethnography is shifted from the position of 'what it can do for archaeology' and instead placed in the hands of descendant communities who have their own conceptions of heritage management?

A great deal of archaeology today revolves around the realm of cultural heritage management, and this is also where many communities come into contact with archaeology. The official mandate of state-sanctioned heritage management has been to identify, evaluate, and protect (where possible) archaeological and other heritage sites that may be affected by development or other activities. ${ }^{\mathrm{I}}$ Within official and professional circles, particularly in North America and Western Europe, cultural heritage management claims to be based on a stewardship model (Society for American Archaeology, I996; Lynott and Wylie, 2000). However, this has for the most part been a unilateral situation of 'we know what's best' that privileges (intentionally or not) Western value systems at the expense of community-based or indigenous ways of relating to so-called 'sites', 'artefacts', and other manifestations of, or ways of knowing, the past. Western archaeology has generally enacted its ethic of 'stewardship' with the view that archaeology is the preferred means to evaluate the past and archaeologists as having the authority to do so on behalf of the public or state (see Groarke and Warrick, 2006; Wylie, 2005; Zimmerman, 2000). Another problematic is the concern that relinquishing control threatens scientific or academic freedom or the integrity of research, when this is actually a prerequisite of decolonization.

The privileged position of archaeological practice and knowledge has been questioned and contended by various descendant peoples, especially by Native Americans and other Aboriginal groups, in debates concerning reburial and repatriation (e.g. Mihesuah, 2000; Bray, 200I). These discussions have been broadened appropriately to include the rights and responsibilities of descendant communities to control, protect, and share aspects of tangible and intangible cultural heritage on their own terms (e.g., Watkins, 2000; Brown, 2003; Smith, 2004; McNiven and Russell, 2005; Anderson, 2006; Atalay, 2006). Native North Americans and Maori from Aoteoroa alike claim special relationships not only to cultural objects but to the cultural knowledge they represent and seek full participation in the protection and management of tangible and intangible heritage (see Bell and Napoleon, 2008). Nevertheless, many archaeologists still have trouble recognizing that descendant or indigenous groups might rightfully have a special relationship to particular aspects of the intellectual and material past (which archaeologists have defined as the 'archaeological record') and their own notions of how to care for these things, which can form the foundation of culturally appropriate forms of 'heritage management'. ${ }^{2}$

To their credit, archaeologists have made strides in recognizing the interests of 'other publics', including descendant peoples, and have strongly promoted goals of 'working together' in the past two decades through 'public archaeology', 'community archaeology', 'indigenous archaeology', and other like-minded practices. ${ }^{3}$ There remains, however, a big disconnection between the involvement of members of descendant communities in archaeology and their full participation in decisions about the management of their own heritage. In many places, descendant communities, and Aboriginal peoples especially, have concerns about the limited input they have in 
heritage management decisions and practices (Heffernan, I988; Smith et al., 2003). At the same time, they may be disturbed about the inability of archaeology to care for sites or handle information in culturally appropriate ways (see Dowdall and Parrish, 2003; McLay et al., 2008). For example, in trying to safeguard culturally sensitive aspects of cultural patrimony, the Penobscot Nation, like many others, is

forced to chose between releasing sensitive IP [intellectual property] material to administrative processes outside of their group, or allowing culturally sensitive places to be desecrated or destroyed because they are unwilling to release the culturally sensitive information that could have prevented that from happening, in either case suffering serious damage to their cultural patrimony. (Wobst, 2008: 3)

Similar dilemmas characterized the well-known Hindmarsh Bridge case in South Australia, in which the Ngarrindjeri community's claim that Hindmarsh Island was sacred based on secret-sacred knowledge was contested, rejected, but later upheld by court decision (see Bell, I999; Weiner, I999; Brown, 2003: I73-I85), and the Hopi struggle to protect secret religious knowledge while substantiating repatriation claims under NAGPRA (Brown, I998: I8).

We have written elsewhere that two of the primary ethical challenges to overcoming archaeology's legacy of scientific colonialism are respect for alternative ways of interpreting and knowing the past, and greater equity in the relations of power and privilege that mark differential access to decision-making, and the ability to have one's decisions count (Nicholas and Hollowell, 2007). As we see it, community-based heritage management is founded on these principles, and the taking back of control over what others have defined as a community's relationship to the past in the present - i.e., its 'heritage' - and the representation, interpretation, and caretaking of this heritage — i.e., its 'management' - is the work of decolonization.

Many inspiring examples exist today of community-based archaeology that incorporate cultural values alongside scientific practice in collaborative research (see Loring, 200I; Ferris, 2003; Budhwa, 2005; Smith and Wobst, 2005; Kerber, 2006; Colwell-Chanthaphonh and Ferguson, 2007; Silliman, 2008). Here, we go a step further and look at the potential use of ethnographic methods by communities to articulate their own customary conceptions of archaeological heritage protection and management, often as a step towards using these as guidelines in policy and decisionmaking in their interactions with external entities. The importance of this cannot be underestimated: as Ros Langford (I983: 4) famously stated, 'if we Aborigines can't control our own heritage, what the hell can we control?' Such feelings carry over to concerns about the appropriation and commodification of many facets of cultural identity, past and present.

Our interest in these topics is situated within a recently funded project that is exploring how, and under what circumstances, issues related to intellectual property ${ }^{4}$ claims and concerns are emerging in the realm of cultural heritage. The project on Intellectual Property Issues in Cultural Heritage; Theory, Policy, Practice, Ethics $(\mathrm{IPinCH})^{5}$ receives its primary funding from the Major Collaborative Research Initiative (MCRI) programme of Canada's Social Science and Humanities Research Council (SSHRC). Over the next three years, the IPinCH project will fund up to twenty community-based initiatives that use ethnographic methods to explore 
community-based concerns about the protection or management of cultural and intellectual heritage, and to locate normative examples of what constitutes good and ethical practice. While one objective of the IPinCH project is to seek successful examples of community-based participatory archaeology to share with others, each individual study will start from the concerns and objectives of a particular group or community and will be designed and implemented by, with, and for them.

Here, we briefly describe three initiatives, one already completed, and two in the research design phase, to illustrate applications of community-based participatory research (CBPR) methodology, also known as participatory action research (PAR), in this context (see also Pyburn, this volume). While we do not intend to promote a particular method that should be exported or used to 'empower' others, we believe that the combination of community-based research and ethnographic approaches can be relevant, useful, and potentially emancipatory in helping a community define its needs regarding the protection and care of tangible and intangible heritage.

\section{Intellectual property issues in cultural heritage}

Since the I980s, new interpretations of rights, ethics, and accountability have prompted major shifts in the policies and practices of archaeologists, anthropologists, descendant communities, governments, museums, and social science researchers as they have confronted challenges related to the politics and ethics of ownership and control over the process and products of archaeology and notions of "who owns the past'. These discussions have focused for the most part on the material and tangible elements of 'official' archaeology and the 'archaeological record' (cf. Hamilakis, 2007: I6), such as the repatriation of objects, curation practices, the antiquities trade, or management of sites. The definition and valuing of tangible subjects and objects of archaeological stewardship as 'cultural property' has placed their control and regulation firmly within the frameworks of Western property law and also subordinate to nationalist or ethnic-based concepts and constructions of patrimony and 'heritage' (see Warren, I999; Smith, 2004). Michael Brown (2004) discusses how reified notions of 'culture' and 'cultural property' tend to place boundaries around things that cannot really be bounded; in fact, archaeology has based much of its interpretative powers on such notions.

Recently, attention has been turning to the intangible or intellectual aspects of cultural objects and practices, without which, one could argue, tangible 'cultural properties' would actually have no meaning or value at all. This has been prompted in part by nationalist, internationalist, and intra-nationalist movements to safeguard 'intangible heritage' and the traditional knowledge of the world's peoples, along with concerns from many corners about the broad local and global implications of $\mathrm{A}_{2} \mathrm{~K}$ (access to knowledge) movements, digital information flows, and the marketing and commodification of cultural goods. This, in turn, has led to new interpretations of rights based on culture and innovative applications of both Western and customary conceptualizations of cultural and intellectual property. ${ }^{6}$

Intellectual property issues related to archaeology and cultural heritage often revolve around claims that descendant communities, ${ }^{7}$ researchers, and others make about access, ownership, or control of cultural knowledge and research products; 
they are concerned with who benefits from research or cultural commodification. Sometimes these concerns translate to restrictions (whether for researchers, the public, or for certain cultural descendants) on access, use, or publication of scientific or cultural information. At the same time, descendant communities and indigenous groups raise well-founded concerns about exploitation of 'cultural knowledge' or other forms of 'intellectual know-how' and the cultural harm that could ensue.

Many different types of intellectual property-related issues are surfacing in the realm of cultural heritage, as illustrated by the following examples:

- the Snuneymuxw First Nation (BC) registered the images on ten ancient petroglyphs as 'official marks' with the Canadian Intellectual Property Office to prevent them from being copied or used commercially (Associated Press, 2000);

- a dispute between Greece and the Republic of Macedonia arose over ancient symbols chosen for the flag of the Macedonian Republic (Hamilakis, 2004);

- in Peru, archaeozoologist Jane Wheeler's DNA bank, based on her research on ancient Inca textiles, is helping to restore a genetic line of alpaca bred centuries ago for its wool, far superior to that available today. Local weavers and large companies are among those interested in benefiting from this research (Pringle, 200I);

- in Australia, the United States, Canada, and elsewhere, indigenous and historic settler groups alike have sought restrictions on the use of artefacts, historic photographs, and ethnographic information; ${ }^{8}$

- a mural commissioned at the University of New Mexico replicating images from the ancient Pottery Mound ruin was cancelled in deference to objections raised by people of Acoma Pueblo, despite their admitting no ancestral association to the site (Duin, 2003);

- legal challenges to scholarly monopolies on access to the Dead Sea Scrolls and publication of findings have forced the release of research results amidst claims of biased interpretation (Carson, I995);

- in Wyoming, prehistoric medicine wheels (rock arrangements) important to Native Americans have been used and even rebuilt by New Age groups (Brown, 2003:I62);

- a Piegan First Nation representative (Alberta) expressed deep concern that their Sundance ceremony had been copyrighted by an individual who had videotaped it, thus deprived the Piegan of their intellectual property;

- In Florida, the Yukon, and the Italian Alps, studies of preserved human tissue from archaeological contexts have led to recovery of patentable ancient genetic material, raising important questions about the role of intellectual property (IP) rights in medical treatments, biotechnology applications, or other scenarios of social or economic benefit involving ancient DNA; 9

- Museums and source communities everywhere are grappling with culturally appropriate data sharing, access to collections, and reciprocal research arrangements. ${ }^{\text {IO }}$ 
In gathering examples of these issues some general themes emerge that traverse the boundaries of public domain, cultural knowledge, and academic or applied research (Figure I). It seems that most intellectual property (IP) concerns arise over issues of protection for specific forms of knowledge - how it is used, who has access, and who benefits. In certain situations, restricting access to knowledge on cultural grounds may well be justifiable (Gervais, 2003; Anderson and Bowrey, 2006). In other situations, IP claims surrounding cultural heritage issues can engender dangerous essentialisms, exclusionary practices, or unjustifiable restrictions on knowledge flows. All of this occurs in a climate where cultural and archaeological heritage has become a global 'resource' - the terra nullius of the 2Ist century (Johnson, 200I).

We agree with Brown that concerns about cultural or intellectual 'property' generally have more to do with community survival and human dignity than with the kinds of economic or legal issues that a term like 'property' suggests. In the world at large, legal protections for intangible heritage as 'intellectual property' apply almost exclusively within the realm of capitalist commerce. Equally problematic are conceptions that portray cultural heritage as the intellectual 'property' of a specific group (Brown, 2003, 2004, 2005). Perhaps we should be talking about ethical and moral issues instead.

In collaboration with other members and partners of the IPinCH project, we are interested in ways in which cultural groups move beyond appeals to Western and

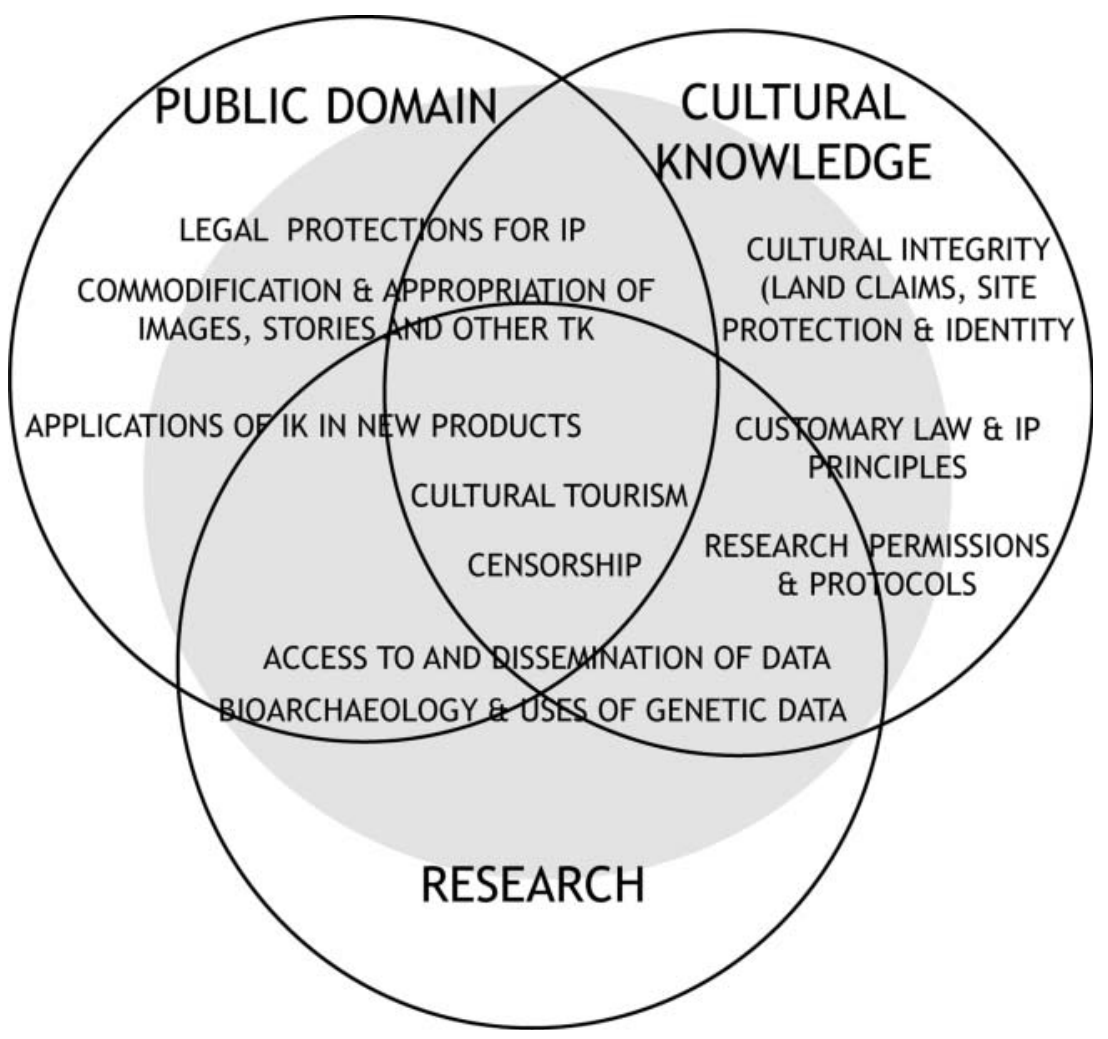

FIGURE 1 Themes related to intellectual property issues in cultural heritage. 
legal concepts of intellectual and cultural property in defining and protecting their relationships to the past and defining their roles and responsibilities in what gets writ large as cultural or archaeological heritage management. This means developing and articulating their own definitions of 'intellectual property', not necessarily based on a capitalist model. As it turns out, commercialization is not always the issue, but rather the right to control how cultural and intellectual property is used and by whom (and this includes within descendant communities themselves). There is an important role here for ethnography in developing more nuanced cross-cultural understandings that explore the variability and key aspects of these issues from grounded experience and situations.

\section{IPinCH community-based initiatives: PAR and ethnography}

A major facet of the IPinCH project is a series of community-based initiatives that employ participatory research and ethnographic approaches to examine how these themes and assumptions play out in specific situations for real people on the ground. ${ }^{\text {II }}$ Community-based participatory research, according to Green (in Minkler and Wallerstein, 2003: 4), is 'a collaborative approach to research that equitably involves all partners in the research process and recognizes the unique strengths that each brings. CBPR begins with a research topic of importance to the community with the aim of combining knowledge and action for social change'. These 'needs-led' studies are characterized by negotiated research practices that build the capacity and expertise of local researchers and share the results and benefits of research among participants and partners. ${ }^{\mathrm{I} 2}$

Community-based approaches have their roots in participatory action research (PAR), a well-established emancipatory methodology that promotes reciprocal and collaborative practices through participation of 'the researched' in the design, implementation, evaluation, and benefits of research. PAR combines tenets of both participatory research (Whyte, I99I) and action research (Freire, I972). It has been described as 'systematic inquiry that is collective, collaborative, self-reflective, critical and undertaken by participants in the inquiry' that seeks to empower participants and foster social change (Rapoport, I990: 499, also cited in Bell and Napoleon, 2008: 9). Wadsworth (I998) notes that PAR 'involves all relevant parties in actively examining together current action (which they experience as problematic) in order to change and improve it'. In recent years, PAR and community-based approaches have successfully been employed by participants in many different sectors, from public health services and illiteracy programmes to community forestry and natural resource management (e.g., Castellanet and Jordan, 2002; Minkler and Wallerstein, 2003).

There are similarities between PAR and community-oriented archaeological projects; both of them ideally involve a partnership in the choice of research problems, co-development of research methodology, and community-targeted benefits. Critics of PAR (e.g., Cooke and Kothari, 200I) have noted that such partnerships are often less democratic than they are purported to be, since the power base and benefits still tend to be skewed towards the outside researcher. Thus, for PAR or CBPR projects to succeed, these potential power imbalances must be identified and 
challenged, something that is facilitated by giving special consideration to community objectives, protocols, and processes. Some of the critical questions that PAR typically addresses, as part of its research design and ethnographic inquiry, include: Whose research is it? Who owns it? Whose intentions does it serve? Who will benefit? Who designs the questions and frames the scope of research? Who will carry it out? Who will write it up? How are results disseminated? (Smith, 2000: Io; also Bell and Napoleon, 2008: I0).

A preliminary list of community-based initiatives came from contacts made as the IPinCH project took shape, through purposive sampling (Yin, 2004), which means that these were situations where people were already looking to explore IP-related issues further. The ethnographic methods used in each study will be chosen by the participants themselves, but these are likely to include interviews, discussion circles, focus groups, oral histories, site visits, and participant observation, often combined with archival research. Raw data (e.g., interview tapes and transcripts) generated during the research will be compiled for the community to curate. Completed reports on each initiative will be available to IPinCH working groups as they continue to explore the implications of intellectual property issues emerging in the realm of cultural heritage. These reports will go through a process of community review and approval before they can be disseminated to the public.

The methodology is borrowed in part from the research design and experiences of another SSHRC-funded project, 'The Protection and Repatriation of First Nation Cultural Heritage', which explored First Nations' concepts of property, law, and heritage protection. ${ }^{\mathrm{I}}$ This project also employed participatory action research methodology in eight community-based initiatives designed and implemented in collaboration with First Nation partners. The choice of PAR methodology was informed by an explicit desire to employ 'decolonizing' research strategies that would foster meaningful collaboration with First Nation partners and produce practical and tangible benefits for them. ${ }^{\text {I4 }}$

The first study described below was completed as part of the project on Protection and Repatriation of First Nation Cultural Heritage and included several IPinCH project members (Nicholas was one) as research collaborators. We then briefly discuss two community-based participatory initiatives that will receive funding from the IPinCH project. Both reveal how concerns about protection for tangible and intangible heritage and related customary practices are entwined with 'official' versions of archaeology, cultural and intellectual property, and heritage management.

\section{The Hul'qumi'num Treaty Group's ethnographic study on heritage law (British Columbia)}

The Hul'qumi'num Treaty Group (HTG) represents six Hul'qumi'num-speaking Coast Salish First Nations located on south-east Vancouver Island and the southern Gulf Islands: the Chemainus, Cowichan, Halalt, Lake Cowichan, Lyackson, and Penelakut. Hul'qumi'num lands lie in an archaeologically rich region of the Pacific Northwest. Members of the HTG have long been concerned about heritage protection issues (see Thom, 2006). Their current interest is heightened by the fact that, like other First Nations across British Columbia, they are deeply involved in negotiating terms of a treaty to settle unresolved land and resource claims, define rights, establish 
self-government, provide funding support, and build government-to-government relations in Canada.

Today over $80 \%$ of the archaeological sites recorded in Hul'qumi'num territory are located off their relatively small parcels of reserve lands. Many of these places have already been developed and others are constantly under threat of development. Members of the HTG desperately want to have a voice in how sites should be treated, and they don't think the world will be 'right' until this happens. However, there are still many in British Columbia who perceive First Nations' interest in archaeology as a political ploy to halt land development or to gain leverage at the treaty table (McLay et al. 2008: 197). While these and other unresolved political issues certainly add fuel to the fire, the interests of Hul'qumi'num peoples in protecting archaeological heritage runs much deeper, as this ethnographic study illustrated.

The HTG study was designed to use ethnographic methods to assist in documenting customary laws and practices related to the protection and care of archaeological heritage. The study had three main goals (see McLay et al., 2008). The first was to facilitate an understanding of Hul'qumi'num customary laws relating to significant places, artefacts, and human remains. In spite of a tradition of silence on these matters, elders had decided it was time to document and share these practices. For many years First Nations felt the best way to protect sacred sites was to keep quiet about them, but with encroaching development people saw that keeping silent was no longer the best strategy (see Mohs, I994); in fact, silence has implied that either there must be few sites that matter or the knowledge of them had been lost.

There's nothing really written down about our sacred things, our sacred ways, sacred areas. We've been brought to question that. Well, other people have said, 'Well, you guys must have not very many important sites that's why it's not recorded'. You know, when we're trying to look at some ... or something about sacred sites. The answer from our home area is: those things that are really sacred, no one is allowed access to. We didn't share it. We don't share it with just anybody. It was good for that day - we kept our heritage, our culture - but today that almost works against us. (Luschiim [Arvid Charlie], in McLay et al., 2008: I5I)

The second goal of the study was to examine problems relating to respect for and enforcement of these customary laws, and the third, to explore how these problems might be addressed. This included how provincial laws might be transformed in ways that mandate a role for Hul'qumi'num peoples in the ownership and management of their archaeological heritage and sites, particularly those located outside of treaty settlement lands.

The study consisted of ethnographic interviews with 22 individuals, and small group discussions with elders and other knowledgeable community members. Notably, HTG members made very few negative references to archaeologists in the interviews. There is a long history of archaeological research in Hul'qumi'num territory, and the community is strongly supportive of research, education and heritage conservation; however, there is also a cultural perception in the Hul'qumi'num community that archaeological work, particularly in relation to burials, can be a socially destructive activity that could cause physical harm for people in the present and offend or disrupt relations with the deceased (see Dowdall and Parrish, 2003 for 
similar feelings among the Kashaya Pomo of California). Many felt archaeological terminology was extremely inappropriate because it so completely disassociated the human element from the sites. For example, the term 'shell midden' was regarded as a very disrespectful way to refer to an ancient village or burial place. What archaeologists called 'archaeological sites' were haunted places, monuments of the ancestors, or cemeteries to the Hul'qumi'num - material evidence of the elaborate, continuing obligations between the living and the dead. Likewise, artefacts were not 'cultural treasures', but belongings that still carried a connection to the person who made or used them long ago. Much like names, artefacts did not belong to people so much as the people belonged to them.

The study's ethnographic findings were summarized in two foundational principles that speak to the obligations that living Hul'qumi'num have in caring for ancestors and sites: (I) Principle of Respect towards places and belongings of the ancestors, and (2) Principle of Reciprocity in relationships between the living and the ancestors, based on a mutually beneficial exchange between them. Each principle was illustrated with thick, narrative descriptions about its meaning and how it should be enacted.

Three primary laws associated with archaeological heritage were also articulated from the ethnographic investigation of Hul'qumi'num heritage practices (see McLay et al., 2008: I57-I72):

\section{Law of Inherited Right to Care for the Dead}

Only persons with the inherited right and ritual knowledge are supposed to care for the remains of the deceased ancestors and their belongings. The Coast Salish had professional ritual specialists who could be hired to perform ceremonial roles regarding the care of the deceased. This is still the case today when human remains are disturbed by natural erosion, land development, or archaeological excavation.

\section{Law of Non-disturbance}

This customary law maintains that it is prohibited to physically disturb any land containing ancient human remains and their belongings. There are also prescriptions about what to do when human remains are disturbed.

\section{Law of Avoidance}

Persons should avoid all physical contact with the spirits of the deceased, their skeletal remains, belongings, and burial grounds. For example, people should not go to graveyards at certain times of day, and weak people should avoid them entirely. People who come in contact with human remains should not go near children or other vulnerable people for a time (usually four days).

The HTG now plans to apply these principles and customary laws to their own heritage management decisions and will also request their observance by outsiders. They want to bring greater public awareness to their interpretations of archaeological heritage and strategically recommend reforms to Canadian heritage law. This use of ethnographic methods and PAR is a powerful and proactive one that could be used by others who want to articulate their own principles of heritage management and renegotiate their position in the highly charged politico-legal terrain of cultural resource management. 


\section{The Moriori Cultural Database (Rekohu/Chatham Islands)}

The Moriori Cultural Database project is an IPinCH community-based initiative coordinated by Moriori lawyer Maui Solomon and archaeologist Susan Forbes and developed by Te Keke Tura Moriori (Moriori Identity Trust), which was established in June 2008 to preserve, revive and promote Moriori identity, culture, language, and heritage. The project is 'an indigenous initiative to record elder knowledge and heritage landscapes, as well as protect Moriori intellectual property' in ways that 'make heritage and IP protection relevant, respectful, and ethical' (Solomon and Forbes, 2008).

Moriori descend from Polynesian people who settled on the islands of Rekohu, also known as the Chatham Islands, $800 \mathrm{~km}$ east of Aoteoroa/New Zealand. They are known for their collective commitment to peace and outlawing of warfare and violence. Waves of intrusions by European explorers and sea mammal hunters, who introduced fatal diseases, and by Maori invaders reduced the Moriori population from around 2500 in I79I (when Europeans first arrived) to IOI adults in I862 (according to census records). These traumas seriously affected the transmission of Moriori cultural knowledge and traditions, and this, in turn, is linked to a decline in sustainable land use and resource management practices. The project's goal of protecting and preserving Moriori intellectual property is also an attempt to protect the islands' land and heritage resources while nurturing economic sustainability.

Previous ethnographic studies on the islands were, typically, conducted by outsiders and, as a result, their contents were incomplete and often inaccurate, with the Moriori having little control over the dissemination of their cultural knowledge. In addition to lacking reference to Moriori knowledge, they were not research-driven. Archaeological work focused on documenting site features to the exclusion of other information. In contrast, the Moriori Cultural Database Project intends to document the multiplicity of values a place holds for people who have cared for it in the past, and present, by combining archival information with archaeological data, oral histories, and information on land-use practices, thus integrating all available layers of knowledge and values associated with a landscape. At the core of the project are interviews with elders, land users and other culture bearers to gather knowledge and experience of place, landscapes, and traditional practices. Much of this work will take place with members of the study team travelling the land with Moriori elders, mapping story places and associated values along the way. ${ }^{15}$ The combined collective information can then be used to inform heritage management decisions from a Moriori standpoint (much like the HTG study above). This cultural information also becomes available for use in today's land and resource management decisions as well as for future generations of Moriori.

By using an indigenous framework in which the research design, philosophy and participants all come from Moriori, the research process develops as a dialogue, a dynamic and intergenerational 'research conversation', that actually encourages collective memory and transfers culturally appropriate knowledge as the research unfolds. Another goal of the project is to develop a model framework for protecting traditional knowledge that others will find useful. Certain Moriori are already serving as mentors to other communities in this regard. 


\section{Ziibiwing Cultural Society and the Sanilac petroglyphs (Michigan)}

While working together on repatriation claims, Ojibwe archaeologist Sonya Atalay and the Ziibiwing Cultural Society found they shared common interests in furthering collaborative projects related to protection of traditional knowledge and intellectual property. The Ziibiwing Cultural Society, a branch of the Saginaw Chippewa Indian Tribe of Michigan that deals with cultural heritage issues, was concerned about an immense rock outcropping, known as ezhibiigaadek asin, located on traditional Saginaw Chippewa lands near Sanilac, on property now owned by the state and managed by the Michigan Department of Natural Resources (DNR). Ezhibiigaadek asin (the Sanilac petroglyph site) comprises over Ioo petroglyphs between 400 and rooo years old. The DNR had placed a roof over them and several interpretive panels around their perimeter, but in 2003, a funding cut caused the agency to close the site, making it more susceptible to harm. The following year the DNR approached the Saginaw Chippewa Indian Tribe about developing some form of co-management.

The tribe's first act was to request access to the site for traditional ceremonies. For the past four years, a cedar bath has been performed, with the images giving their teachings as four generations of women move across the site, cleansing it with cedar boughs. The Saginaw Chippewa's own teachings tell them that aspects of these ancient stories and teachings need to be shared with others, and the Cultural Society has invited the public to attend and even participate in the cedar bath. But there are concerns about how to continue sharing knowledge about this sacred place in a way that, at the same time, protects it from potential misuse. Especially worrisome is the potential for commercial use of the images, whether to promote the site or for other ventures. Many people have been drawn to one particular image, of an archer. In February 2008, a tribal member opened a sporting goods store and enquired with the Ziibiwing Center about using the archer as a logo. They were refused, not only on grounds that the image should not be used commercially, ${ }^{16}$ but also because the archer's teachings have nothing to do with hunting; instead, he is shooting ancestral knowledge into the future, so that it will be available to the people.

The Anishinabe people believe that knowledge is not owned by any one person - it belongs to the whole community - but there is a sense of knowledge stewardship, in which individuals are responsible for its protection. The question is how to enact this proactively with the petroglyphs, without really knowing how things might play out in the world today. This community-based initiative - developed by Atalay, the Ziibiwing Center of Anishinabe Culture and Lifeways, and the Saginaw Chippewa Indian Tribe of Michigan - will interview elders, other tribal members, and DNR officials about the best ways to manage the site and its teachings. This ethnographic information will facilitate forming a policy that incorporates an active role for tribes in the management and protection of the site and its associated knowledge, while also considering the needs of non-Native visitors. Similar issues concerning rock art and rock art sites are cropping up in other places, as if they are a lightning rod for intellectual property concerns, and what happens at Sanilac is likely to have ramifications for other sites in the region and beyond. 


\section{Discussion}

Ethnography in archaeology has primarily served to promote the goals and objectives of archaeology. Here we consider a different paradigm; one where ethnography is employed to ground heritage management in customary principles and practices defined by descendant communities. The three examples presented here provide some inspiring ways for communities to use ethnographic methods to articulate local or customary laws and principles of heritage management that place more control over the process, products, and interpretation of 'archaeology' or 'cultural heritage' in the hands of those at the source. In one sense, this is an emancipatory use of ethnography for Native groups and not of Native groups - one that offers a means by which they may be empowered to articulate and put forth their own principles of heritage law and heritage management. We would hope that others might be inspired by these examples to conduct their own ethnographic studies to help facilitate alternative grounded and local understandings of heritage management.

As for archaeologists, we have left them almost entirely out of the picture. These examples are in fact not meant as ways to show what ethnography can do for 'official' archaeology, but as 'ethnographies of archaeologies' (see Mortensen and Hollowell, 2009) that employ community-based ethnographic research to move heritage management away from the realm of 'what it can do for archaeology' and place it in the hands of a descendant community. As for examining what better cultural heritage management practices or archaeological ethnographies can do for archaeologists, there is definitely a place for this, but it comes later; in the negotiations and compromises that the Hul'qumi'num Treaty Group, the Hokotehi Moriori Trust, or the Saginaw Chippewa will undoubtedly be asked to make as they work out how their own principles and versions of heritage management mesh with the dominant or official system, and as they strategize how they might want to affect or change policies at the state level. Just how community-based principles might articulate with external heritage policies and legislation is something that needs to be discussed and negotiated by the community and others. We would suggest that these contexts represent another important application for ethnography, as exemplified by the collaborative work of Catherine Dowdall and Otis Parrish (2003) who not only facilitated an ethnography of archaeological heritage practices for and with the Kashaya Pomo in California but also conducted an ethnography of CalTran, the state agency charged with cultural resource management on Kashaya lands. With a better understanding of CalTran's positions and policies gained through the ethnographic study, the Kashaya find themselves in a much stronger position to make betterinformed decisions about how to enact their own heritage management policies and where they are and are not willing to compromise. This, in fact, is what applied ethics are all about.

In Table I, we have juxtaposed two statements - one from the Society of American Archaeology (SAA) (a certain kind of 'imagined community') and the other derived from the ethnographic study (discussed above) conducted by the Hul'qui'num Treaty Group in British Columbia - to illustrate some of the essential differences between the community-based principles of Hul'qumi'num heritage law and the SAA's first principle of archaeological ethics, stewardship. Whereas one commits to preserve and protect the 'archaeological record' 'for the benefit of all people', 
TABLE 1

\begin{tabular}{|c|c|}
\hline $\begin{array}{l}\text { SAA's Principles of Archaeological Ethics - Principle } \\
\text { No. 1: Stewardship }\end{array}$ & $\begin{array}{l}\text { Hul'qumi'num Treaty Group (HTG) - Hul'qumi'num } \\
\text { Heritage Law }\end{array}$ \\
\hline $\begin{array}{l}\text { The archaeological record, that is, in situ } \\
\text { archaeological material and sites, archaeological } \\
\text { collections, records and reports, is irreplaceable. It } \\
\text { is the responsibility of all archaeologists to work } \\
\text { for the long-term conservation and protection of } \\
\text { the archaeological record by practicing and } \\
\text { promoting stewardship of the archaeological } \\
\text { record. Stewards are both caretakers of and } \\
\text { advocates for the archaeological record for the } \\
\text { benefit of all people; as they investigate and } \\
\text { interpret the record, they should use the } \\
\text { specialized knowledge they gain to promote } \\
\text { public understanding and support for its long- } \\
\text { term preservation' (SAA, 1996). }\end{array}$ & $\begin{array}{l}\text { 'Hul'qumi'num people's archaeological heritage is } \\
\text { integral to their distinctive cultural identity. Archaeologi- } \\
\text { cal heritage is valued for its relation to "people", rather } \\
\text { than as "objects" of material value. Archaeological sites } \\
\text { are perceived not as abstract scientific resources, but } \\
\text { as the "cemeteries" of family Ancestors. From a } \\
\text { Hul'qumi'num perspective, the Living have obligations to } \\
\text { the continuity of relations between the Living and the } \\
\text { Ancestors. The deceased remains and belongings are } \\
\text { believed to possess powers dangerous to the Living, } \\
\text { thus Hul'qumi'num culture maintains strict customary } \\
\text { laws associated with the treatment of the deceased } \\
\text { Ancestors and their belongings' (McLay et al. 2004: ii). }\end{array}$ \\
\hline
\end{tabular}

the other seeks to preserve and protect relationships between the living and the dead for the benefit of a distinct cultural group. One emphasizes responsibilities to objects from the past in the present; the other focuses on obligations to people, both past and present. Both refer to specialized knowledge, but in very different terms and with very different goals. While one group uses its specialized knowledge primarily to protect the 'archaeological record', the other uses it to follow customary laws associated with how to treat the dead and their belongings. This is a telling example of how community-based principles of archaeological heritage and management may be founded on fundamentally different worldviews or conceptions of what constitutes 'stewardship'.

Heritage management principles derived from source communities and customary practices shed light on alternative ways of conceiving preservation, stewardship, or archaeological value. Ethnography is invaluable in understanding complex issues of protection and control that surround both the intellectual and material aspects of archaeological heritage. We encourage further ethnographic inquiry into topics such as these to help us all understand the diversity of issues, the context, and the range of often innovative choices people make in situations characterized by differential access to information, resources, and power. Archaeologists desperately need ethnographic examples of community-based conceptions of heritage management to expand their awareness of the complex webs of obligations and responsibilities spun on what they and the state have termed 'archaeological resources'. Critical and participatory ethnographic approaches go far in helping to define more effective, and ultimately more rewarding, research methodologies (see Denzin et al., 2008) that contribute to a more nuanced approach to heritage in its many different, sometimes contradictory, manifestations (see Bell and Napoleon, 2008).

Words such as 'resource management' or 'cultural property' immediately signal the use and commodity value of both tangible and intangible iterations of the past in global economic and political regimes (see Hamilakis, 2007). Instead, like Michael Brown (2004), Jeanette Greenfield (2007), and others, we agree that context-specific local negotiations based on mutual respect among different standpoints are far more 
appropriate and effective for working through issues related to intellectual or cultural 'property' and heritage management than legal mechanisms, which, typically, require bounded and static definitions of cultural affiliation and culture as property. As Brown notes (2004: 60), these 'totalizing legal strategies' are hardly compatible with community-based approaches. As an alternative, we argue that participatory research on community-based principles of heritage management with a strong ethnographic component is an appropriate, enlightening, and potentially emancipatory way to better understand some of the slippery issues that characterize intersections among property, heritage, and culture.

\section{Acknowledgments}

We thank Yannis Hamilakis and Aris Anagnostopoulos for their tireless energy and astute comments, as well as all those who attended the workshop in Poros. Special thanks to Eric McLay and Brian Thom, who reviewed and contributed suggestions for the portion on heritage law for the Hul'qumi'num Treaty Group; to Susan Forbes for reviewing the segment on the Moriori Cultural Database project, and to Sonya Atalay for providing comments on the Sanilac Petroglyph study. We acknowledge our gratitude to the the Hul'qumi'num Treaty Group, to Te Keke Tura Moriori (Moriori Identity Trust), and to the Ziibiwing Cultural Society for their engagement with this work and their support in its dissemination.

\section{Notes}

I See Cleere, I988; McManamon and Hatton, I999; Neumann and Stanford, 200I; Smith, 2004; also the journal Heritage Management edited by HaysGilpin and Gumerman.

2 See McGhee, 2008 on maintaining archaeological privilege, and Colwell-Chanthaphonh et al. (forthcoming) for counterpoint.

3 For examples, see Nicholas and Andrews, I997; Swidler et al., I997; Derry and Malloy, 2003; Shackel and Chambers, 2004; Smith and Wobst, 2005; Colwell-Chanthaphonh and Ferguson, 2007; Shackel and Little, 2007; Nicholas, 2008.

4 Dratler (I994: I-2) defines 'intellectual property' (IP) as 'intangible personal property in creations of the mind'. While Western law narrowly defines IP in terms of commercial rights (patents, copyrights, trademarks), our concern is with IP issues within and beyond Western legal frameworks. See Brown, 2004 for a thoughtful review of tangible and intangible culture as property.

5 For more information about this international collaboration of archaeologists, anthropologists, lawyers, indigenous organizations, museum specialists, ethicists, and policy-makers from eight countries, see the IPinCh website at http://www.sfu.ca/ ipinch.

6 See Hirsch and Strathern, 2004; Cowan, 2006; Strathern, 2006; for a critical, problematic perspective on cultural rights and heritage as property, see Brown, 2004, 2005).

7 Defining who or what constitutes a 'descendant community' can be problematic, but we concur with Dean Saitta (2007: 275) who refers to descendant communities as those groups who, regardless of geography, ancestry, or background, identify with a particular past or locale through shared traditions, proximity, or collective memories.

8 See Farrer, I994; Ferguson and Anyon, I996; Montejo, I999; Brown, 2003, especially Chapters I and 2; Anderson, 2006. See First Archivists' Circle, 2007 and AIATSIS, 2000 for suggested protocols for archival materials.

9 See Doran et al., I986; Spindler, I994; Beattie, et al. 2000; Nicholas and Bannister, 2004a, 2004b; Nicholas, 2005; Hollowell and Nicholas, 2009.

${ }^{\text {10 }}$ For example, see the Reciprocal Research Network formed by a partnership among the Musqueam Indian Band, the Sto:lo Nation and Sto:lo Tribal Council, the U'mista Cultural Society, and University of British Columbia's Museum of Anthropology (<http://www.moa.ubc.ca/RRN/about_overview. html>) Last accessed: 2 August 2009.

II The committee of social scientists that evaluated the IPinCH proposal for SSHRC was initially wary of our methodological grounding in critical theory and PAR. They were concerned that research designs 
would not be completely worked out ahead of time and instead were to be negotiated collaboratively. We had to build a strong rationale for 'multiple case study' research that would be ethnographic, community-based, and participatory. In fact, we had to make a strong case for using qualitative research at all, and we had to do this using terminology that social scientists wanted to hear.

${ }^{I 2}$ Features absent in cases such as the 'Kennewick Man' controversy over an ancient human whose fate and ancestry bitterly galvanized US cultural heritage policies. See Thomas, 2000; Watkins, 2000; Bruning, 2006; Burke et al. 2008.

I3 The 'Project for Protection and Repatriation of First Nation Cultural Heritage' was directed by Catherine Bell and Robert Paterson and funded by SSHRC's Aboriginal Research programme. More information about the project and access to its case studies can be found at www.law.ualberta.ca/research/aboriginalculturalheritage/ Last accessed: 2 August 2009.
${ }^{\text {I4 }}$ For a thorough discussion of some of the challenges and inherent contradictions involved in PAR, see Bell and Napoleon's (2008) introduction to the two published volumes on the results of this research project.

I5 See also Ferguson and Colwell-Chanthaphonh (2006), who facilitated a similar process with representatives of the four tribes whose histories are connected with the San Pedro Valley region.

${ }^{16}$ Even in the Ziibiwing Center, the museum of the Saginaw Chippewa Indian Tribe, use of the archer image is not permitted unless it has been altered, due to the belief that its depiction can drain power from the image. The Maori had similar beliefs concerning the portrayal of a sacred mountain in the Lord of the Rings movies, and this is why Peter Jackson, the director, consulted with Maori representatives as to what to do and decided to alter the image digitally (see Perry, 2003).

\section{References}

AIATSIS (Australian Institute of Aboriginal and Torres Strait Islander Studies) 2000 Guidelines for ethical research in indigenous studies < http://www.wipo.int/tk/en/folklore/creative_heritage/researchers/linkooo3.html> [Last accessed 2I January 2009].

Anderson, J 2006 Indigenous knowledge and intellectual property: access, ownership and control of cultural materials. Report for the Australian Institute of Aboriginal and Torres Strait Islander Studies (3I March).

Anderson, J and C Bowrey 2006 The cultural politics of the IP commons: whose agendas are being advanced? Australian Intellectual Property Law Resources I7 <http://www.austlii.edu.au/au/other/AIPLRes/2006/I7.html> [Last accessed 20 July 2009].

AP (Associated Press) 2000 Indian band applies for trademark on ancient petroglyph. State and Local Wire, February I6. (on file with authors).

Atalay, S (ed.) 2006 Decolonizing archaeology (special issue). American Indian Quarterly 30(I).

Beattie, O, B Apland, E W Blake, J A Cosgrove, S Gaunt, S Greer, A P Mackie, K W Mackie, D Straathof, V Thorp and P M Troffe 2000 The Kwäday Dän Ts'inchi discovery from a glacier in British Columbia. Canadian Journal of Archaeology 24(I) I29-I48.

Bell, D 1999 Ngarrindjeri Wurruwarrin: A world that is, was and will be. Spinifex Press, North Melbourne, Austrailia.

Bell, C and V Napoleon 2008 Introduction, methodology and thematic overview. In: Bell, C and V Napoleon (eds) First nations cultural heritage and law: case studies, voices and perspectives. UBC Press, Vancouver, I-32.

Bell, C and V Napoleon (eds) 2008 First nations cultural heritage and law: case studies, voices and perspectives. UBC Press, Vancouver.

Bray, T L (ed.) 200I The future of the past: archaeologists, Native Americans and repatriation. Garland, New York.

Brown, M F 1998 Cultural records in question: information and its moral dilemmas. CRM (Cultural Resource Management) 2I(6) I8-20.

Brown, M F 1999 Can culture be copyrighted? Current Anthropology 39(2) I93-222.

Brown, M F 2003 Who owns native culture? Harvard University Press, Cambridge, MA.

Brown, M F 2004 Heritage as property. In: Verdery, K and C Humphrey (eds) Property in question: value transformation in the global economy. Berg, Oxford, 49-68.

Brown, M F 2005 Heritage trouble: recent work on the protection of intangible cultural property. International Journal of Cultural Property $\mathrm{I} 2$ 40-6I.

Bruning, S 2006 Complex legal legacies: The Native American Graves Protection and Repatriation Act, scientific study, and Kennewick Man. American Antiquity 7I(3) 50I-522. 
Budhwa, R 2005 An alternate model for First Nations involvement in resource management archaeology. Canadian Journal of Archaeology 29 20-45.

Burke, H, C Smith, D Lippert, J Watkins and L Zimmerman (eds) 2008 Kennewick Man: perspectives on the ancient one. Left Coast Press, Walnut Creek, CA.

Carson, C 1995 Raiders of the lost ark: the right of scholarly access to the content of historical documents. Michigan Journal of International Law 16 300-348.

Castellanet, C and C F Jordan 2002 Participatory action research in natural resource management. Taylor \& Francis, New York.

Cleere, H (ed.) I988 Archaeological heritage management in the modern world. Routledge, London.

Colwell-Chanthaphonh, C and T J Ferguson (eds) 2007 The collaborative continuum: archaeological engagements with descendant communities. AltaMira Press, Lanham MD.

Colwell-Chanthaphonh, C, T J Ferguson, D Lippert, R H McGuire, G P Nicholas, J E Watkins and L J Zimmerman forthcoming Untangling the strawman: inclusion, rights, ethics, and the promise of indigenous archaeology. A response to Robert McGhee. Ms submitted to American Antiquity.

Cooke, B and U Kothari (eds) 200I Participation: the new tyranny? Zed Books, London.

Cowan, J 2006 Culture and rights after culture and rights. American Anthropologist 108 9-24.

Denzin, N K, Y S Lincoln and L T Smith (eds) 2008 Handbook of critical and indigenous methodologies. Sage, Thousand Oaks, CA.

Derry, L and M Malloy (eds) 2003 Archaeologists and local communities: partners in exploring the past. Society for American Archaeology, Washington, D.C.

Doran, G, D N Dickel, W E Ballinger Jr, O F Agee, P J Laipis and W W Hauswirth I986 Anatomical, cellular, and molecular analysis of 8,000-yr-old human brain tissue from the Windover archaeological site. Nature 325 $803-806$.

Dowdall, K and O Parrish 2003 A meaningful disturbance of the earth. Journal of Social Archaeology 3(I) 99-133.

Dratler, J 1994 Licensing of intellectual property. Law Journal Seminars-Press, New York.

Duin, J 2003 Tribes veto southwest mural. Washington Times, I8 February <http:/www.nathpo.org/News/ NAGPRA/News-NAGPRA29.htm> Last accessed 20 July 2009.

Farrer, C R 1994 Who owns the words? An anthropological perspective on Public Law IoI-60I. Journal of Arts Management, Law and Society 23(4) 3I7-326.

Ferguson, T J and C Colwell-Chanthaphonh 2006 History is in the land: multivocal tribal traditions in Arizona's San Pedro Valley. University of Arizona Press, Tucson.

Ferguson, T J and R Anyon 1996 Repatriation at the Pueblo of Zuni: diverse solutions to complex problems. American Indian Quarterly 20(2) 25I-274.

Ferris, N 2003 Between colonial and indigenous archaeologies: legal and extra-legal ownership of the archaeological past in North America. Canadian Journal of Archaeology 27 I54-I90.

First Archivists' Circle 2007 Protocols for Native American archival materials < http://www2.nau.edu/libnap-p/ protocols.html> [Last accessed 2I January 2009].

Freire, P I972 Cultural action for freedom. Penguin, Harmondsworth, Middlesex.

Gervais, D J 2003 Spiritual but not intellectual? The protection of sacred intangible traditional knowledge. Cardozo Journal of International and Comparative Law II 467-495.

Greenfield, J 2007 The return of cultural treasures. 3rd ed. Cambridge University Press, Cambridge.

Groarke, L and G Warrick 2006 Stewardship gone astray? Ethics and the SAA. In: Scarre, C and G Scarre (eds) The ethics of archaeology: philosophical perspectives on archaeological practice. Cambridge University Press, Cambridge, I63-180.

Hamilakis, Y 2004 Comments on 'copyrighting the past?' emerging intellectual property rights issues in archaeology, by George Nicholas and Kelly Bannister. Current Anthropology 45(3) 343-344.

Hamilakis, Y 2007 From ethics to politics. In: Hamilakis, Y and P Duke (eds) Archaeology and capitalism: from ethics to politics. Left Coast Press, Walnut Creek, CA, I 5-40.

Heffernan, T F 1988 Wood Quay: the clash over Dublin's Viking past. University of Texas Press, Austin, TX.

Hirsch, E and M Strathern (eds) 2004 Transactions and creations: property debates and the stimulus of Melanesia. Berghahn, Oxford. 
Hollowell, J and G Nicholas (eds) 2009 Decoding implications of the Genographic Project for archaeology and cultural heritage. Special section of the International Journal of Cultural Property 16(2).

Johnson, V 200I Getting over terra nullius. Paper presented at the Australian Registrars Committee Conference. Melbourne, Australia. http://www.eniar.org/news/arti3.html Last accessed 2I July 2009.

Kerber, J (ed.) 2006 Cross-cultural collaboration: Native peoples and archaeology in the northeastern United States. University of Nebraska Press, Lincoln.

Langford, R 1983 Our heritage, your playground. Australian Archaeology I6 I-IO.

Loring, S 200I Repatriation and community anthropology: The Smithsonian Institution's Arctic Studies Center. In: Bray, T (ed.) The future of the past: archaeologists, Native Americans and repatriation. New York, Garland, I $85-200$.

Lynott, M J and A Wylie (eds) 2000 Ethics in American archaeology: challenges for the 9os (2nd edn). Society for American Archaeology, Washington DC.

McGhee, R 2008 Aboriginalism and the problems of indigenous archaeology. American Antiquity 73(4) 579-597.

McLay, E, K Bannister, L Joe, B Thom and G P Nicholas 2004 'A'lhut tu tet Sul'bweentst - 'Respecting the Ancestors': Report of the Hul'qumi'num heritage law case study. Project for Protection and Repatriation of First Nation Cultural Heritage. Hul'qumi'num Treaty Group and Social Sciences and Humanities Research Council (SSHRC) <http://www.law.ualberta.ca/research/aboriginalculturalheritage/researchpapers.htm> Last accessed 2 August 2009.

McLay, E, K Bannister, L Joe, B Thom and G P Nicholas 2008 A'lhut tu tet Sul'hweentst [Respecting the ancestors]: Understanding Hul'qumi'num heritage laws and concerns for protection of archaeological heritage. In: Bell, C and V Napoleon (eds) First Nations cultural heritage and law: cases studies, voices and perspectives. UBC Press, Vancouver, I58-202.

McManamon, F and A Hatton 1999 Introduction: considering cultural resource management in the modern world. In: McManamon, F (ed.) Cultural resource management in contemporary society: perspectives on managing and presenting the past. Routledge, London, I-2I.

McNiven, I J and L Russell 2005 Appropriated pasts: indigenous peoples and the colonial culture of archaeology. AltaMira Press, Lanham, MD.

Mihesuah, D A (ed.) 2000 Repatriation reader: who owns American Indian remains? University of Nebraska Press, Lincoln.

Minkler, M and N Wallerstein (eds) 2003 Community based participatory research for health. Jossey-Bass, San Francisco, CA.

Mohs, G 1994 Sto:lo sacred ground. In: Carmichael, D L, J Hubert, B Reeves and A Schanche (eds), Sacred sites, sacred places. Routledge, London, I84-208.

Montejo, V D 1999 The year bearer's people: repatriation of ethnographic and sacred knowledge to the Jakaltek Maya of Guatemala. International Journal of Cultural Property 8(I) I5I-I66.

Mortensen, L and J Hollowell (eds) 2009 Ethnographies and archaeologies: iterations of the past. University Press of Florida, Gainesville.

Neumann, T W and R M Sanford 200I Cultural resources archaeology: an introduction. AltaMira Press, Walnut Creek, CA.

Nicholas, G P 2005 On mtDNA and archaeological ethics. Canadian Journal of Archaeology 29(2) iii-vi.

Nicholas, G P 2008 Native peoples and archaeology. In: Pearsall, D (ed.) Encyclopedia of archaeology, vol. 3. Elsevier, Oxford, I660-I669.

Nicholas, G P and J Hollowell 2007 Ethical challenges to a postcolonial archaeology. In: Hamilakis, Y and P Duke (eds) Archaeology and capitalism: from ethics to politics. Left Coast Press, Walnut Creek, CA, 59-82.

Nicholas, G P and K P Bannister 2004a Intellectual property rights and indigenous cultural heritage in archaeology. In: Riley, M (ed.) Indigenous intellectual property rights: legal obstacles and innovative solutions. AltaMira Press, Walnut Grove, CA, 309-340.

Nicholas, G P and K P Bannister 2004b Copyrighting the past? Emerging intellectual property rights issues in archaeology. Current Anthropology 45(3) 327-350.

Nicholas, G P and T D Andrews (eds) 1997 At a crossroads: archaeology and first peoples in Canada. Archaeology Press, Burnaby, BC. 
Perry, M 2003 Digital propertization of the new artifacts: the application of technologies for 'soft' representations of the physical and metaphysical. Cardozo Journal International and Comparative Law in 67I-705.

Pringle, H 200I Secrets of the alpaca mummies. Discover (Magazine) 22(4).

Rapoport, R I990 Three dilemmas in action research. Human Relations 23(6) 499-5I4

Saitta, D 2007 Ethics, objectivity, and emancipatory archaeology. In: Hamilakis, Y and P Duke (eds) Archaeology and capitalism: from ethics to politics. Left Coast Press, Walnut Creek, CA, 267-280.

Shackel, P and B Little 2007 Archaeology as a tool of civic engagement. AltaMira Press, Lanham, MD.

Shackel, P and E Chambers 2004 Places in mind: archaeology as applied anthropology. Routledge Press, NY.

Silliman, S (ed.) 2008 Collaborating at the trowel's edge: teaching and learning in indigenous archaeology. University of Arizona Press, Tuscon.

Smith, L 2004 Archaeological theory and the politics of cultural heritage. Routledge, London.

Smith, L T 2000 Decolonizing methodologies: research and indigenous peoples. Zed Books, New York.

Smith, C and H M Wobst (eds) 2005 Indigenous peoples and archaeology: the politics of practice. Routledge, London.

Smith, L, A Morgan and A van der Meer 2003 The Waanyi Women's History Project: a community project, Queensland, Australia. In: Derry, L and M Molloy (eds) Archaeologists and local communities: partners in exploring the past. SAA Press, Washington, DC, I47-I65.

Society for American Archaeology (SAA) I996 Principles of archaeological ethics. American Antiquity 6I 45I-452 $<$ http://www.saa.org/AbouttheSociety/PrinciplesofArchaeologicalEthics/tabid/203/Default.aspx> Last accessed 2 August 2009.

Solomon, M and S Forbes 2008 Moriori Cultural Database: IPinCH case study proposal. Research proposal submitted to the Intellectual Property Issues in Cultural Heritage Project, Simon Fraser University, Burnaby, BC.

Spindler, K 1994 The man in the ice. Weidenfield and Nicolson, London.

Strathern, M 2006 Intellectual property and rights: an anthropological perspective. In: Tilley, C, W Keane, S Kuechler-Fogden, R Rowlands and P Spyer (eds) Handbook of material culture. Sage Publications, London, $447-462$.

Swidler, N, K E Dongoske, R Anyon and A S Downer (eds) 1997. Native Americans and archaeologists: stepping stones to common ground. AltaMira, Walnut Creek, CA.

Thom, B 2006 Respecting and protecting Aboriginal intangible property: copyright and contracts in research relationships with Aboriginal communities. Report to Department of Canadian Heritage, Copyright Policy Branch, Ottawa. PCH Contract 45172644 .

Thomas, D H 2000 Skull wars: Kennewick Man, archaeology, and the battle for Native American identity. Basic Books, New York.

Wadsworth, Y I998 What is participatory action research? Action Research International, Paper 2 <http://www. scu.edu.au/schools/gcm/ar/ari/p-ywadsworth98.html> [Last accessed 2I January 2009].

Warren, K J 1999 A philosophical perspective on the ethics and resolution of cultural property issues. In: Messenger, P M (ed.), The ethics of collecting cultural property: whose culture? whose property?, University of New Mexico, Albuquerque, I-38.

Watkins, J E 2000 Indigenous archaeology: American Indian values and scientific practice. Altamira Press, Walnut Creek, CA.

Weiner, J F 1999 Culture in a sealed envelope: the concealment of Australian Aboriginal heritage and tradition in the Hindmarsh Bridge affair. Journal of the Royal Anthropological Institute 5 I93-2Io.

Whyte, W F (ed.) I99I Participatory action research. Sage Publications, Newbury Park, CA.

Wobst, H M 2008 Developing policies and protocols for the culturally sensitive intellectual properties of the Penobscot Nation of Maine. Research proposal submitted to the Intellectual Property Issues in Cultural Heritage Project, Simon Fraser University, Burnaby, BC.

Wylie, A 2005 The promise and perils of an ethic of stewardship. In: Meskell, L and Pels, P (eds.) Embedding ethics. Berg, Oxford, 47-68.

Yin, R K 2004 Case study research: design and methods. Sage Publications, Thousand Oaks, CA.

Zimmerman, L J 2000 Regaining our nerve: ethics, values, and the transformation of archaeology. In: Lynott, M $\mathrm{J}$ and A Wylie (eds) Ethics in American archaeology: challenges for the I99os (2nd edn). Society for American Archaeology, Washington DC, 64-67. 


\section{Notes on Contributors}

The authors are series co-editors for the World Archaeological Congress Research Handbooks in Archaeology.

Julie Hollowell is the Nancy Schaenen Visiting Scholar at the Janet Prindle Institute for Ethics and visiting professor of anthropology at DePauw University. Her interests lie in the area of ethics issues in cultural heritage and archaeology; multiple claims on the material and intellectual past; and the repatriation of knowledge, materials, and research directives to source communities.

George Nicholas is professor of archaeology, Simon Fraser University, and director of the Intellectual Property Issues in Cultural Heritage Project (www.sfu.ca/ IPinCulturalHeritage). His research focuses on indigenous peoples and archaeology, intellectual property issues, the archaeology and human ecology of wetlands, and archaeological theory.

Correspondence to: Julie Hollowell, Department of Sociology and Anthropology, DePauw University, 329 Asbury Hall, Greencastle, IN 46I35, USA. Email: juliahollowell@depauw.edu 